\title{
REVISION OF THE SKELETAL MORPHOLOGY OF EODISCOGLOSSUS SANTONJAE, AN EARLY CRETACEOUS FROG FROM NORTHEASTERN SPAIN, WITH COMMENTS ON ITS PHYLOGENETIC PLACEMENT
}

\author{
ANA MARIA BÁEZ1, ${ }^{*}$, RAÚL O. GÓMEZ1 \\ ${ }^{1}$ Consejo Nacional de Investigaciones Científicas y Técnicas, Facultad de Ciencias Exactas y Naturales, Universidad de Buenos Aires, Departamento \\ de Ciencias Geológicas, Pabellón 2, Ciudad Universitaria, 1428 Buenos Aires, Argentina. \\ * corresponding author: baezanam@yahoo.com.ar
}

Báez, A. M., Gómez, R. O. (2016): Revision of the skeletal morphology of Eodiscoglossus santonjae, an Early Cretaceous frog from northeastern Spain, with comments on its phylogenetic placement. - Fossil Imprint, 72(1-2): 67-77, Praha. ISSN 25334050 (print), ISSN 2533-4069 (on-line).

\begin{abstract}
The holotype of the "archaeobatrachian" (i.e., non-neobatrachian) frog Eodiscoglossus santonjae VILLALTA, 1954 is redescribed herein, with focus on some features that have been misinterpreted. The specimen is articulated and poorly preserved as fragmentary bones and impressions, and is from the Early Barremian La Pedrera de Rúbies Lithographic Limestones Formation at Santa Maria de Meià, Lleida Province. Other specimens from the same fossil site and unit are also examined and their former allocation to the same species critically reconsidered, with the conclusion that more than one taxon might be represented in this sample. Previous viewpoints on the systematic placement of E. santonjae, usually considered a discoglossid, are assessed. However, a full revision of the Jurassic and Cretaceous specimens ascribed to the genus is required in order to resolve its phylogenetic position. Hence, E. santonjae is provisionally considered as Anura incertae sedis.
\end{abstract}

Key words: Discoglossidae, Alytidae, Cretaceous, Santa Maria de Meià, Sierra de Montsec, La Pedrera de Rúbies Lithographic Limestones

Received: January 29, 2016 | Accepted: April 11, 2016 | Issued: August 15, 2016

\section{Introduction}

Although scattered in time and space, in the latter two decades several fossil finds from the Early and mid Cretaceous have provided increasing evidence for the divergence of the main lineages within the crown-group Anura (e.g., Gao and Wang 2001, Gao and Chen 2004, Báez et al. 2009, Báez 2013), suggesting that this period of time witnessed most of the basal cladogenetic events in this taxon. However, in many instances the incomplete or poor preservation of remains of this age do not allow us to determine their taxonomic placement unambiguously, and rigorous reinterpretation of different character states, sometimes with the inclusion of additional finds, is crucial (e.g., Báez and Sanchiz 2007, Dong et al. 2013).

In a brief account of the latest paleontological discoveries between 1952-1954 published on the occasion of the II Cursillo Internacional de Paleontología at the Sabadell Museum of Spain (previously dated as 1956 but now established as 1954 according to Martin et al. 2012), J.F. de Villalta Comella announced the find of a new frog discovered by J. Ferrer in the well-known fossiliferous lithographic limestones at Santa Maria de Meià, Sierra de Montsec, province of Lleida, and listed some diagnostic features. The bearing beds were formerly assigned to the Late Jurassic but at present are considered of Early Cretaceous age (Early Barremian) (Ansorge 1995, Martínez-Closas and López Morón 1995). Although the fossil material was not described in detail at the time, it was estimated to represent a new "primitive discoglossid" and thus named Eodiscoglossus santonjae VILLALTA, 1954 (Villalta 1954). Almost simultaneously, the specimen was figured by Piveteau (1955: 269) and a photograph with a brief comment was presented in the Spanish edition of the work of Leonardi directed by B. Melendez (Leonardi 1957). Later on, Hecht (1963) made passing comments on a few features of this taxon but subsequently published a complete description of the holotype (Hecht 1970), which consists of an articulated skeleton preserved on two slabs as part and counterpart that he considered to represent a discoglossid frog. Hecht (1970) also provided fluorescence photographs of both parts, one of which is available for examination at the Museo Nacional de Ciencias Naturales de Madrid (MNCN 4723, Text-fig. 1), whereas the other one was previously in a private collection (Colección Ferrer-Condal en Tirvia, Lleida) but its whereabouts are at present unknown (Martin et al. 2012; Sanchiz, pers. comm. 2015). Shortly afterwards, Estes and Reig (1973) listed the main anatomical characters of E. santonjae and presented a skeletal reconstruction in dorsal view. 
Additional specimens were subsequently collected in the same quarry, some of which were provisionally ascribed to this species by Vergnaud-Grazzini and Wenz (1975). These specimens vary greatly in size and belong to different growth stages. As discussed below, features of some of these specimens, housed in the Museum d'Histoire Naturelle (MNHN) in Paris, differ from the described characters of the holotype of E. santonjae. Although some of these differences might reflect ontogenetic variation, referral to this species should be confirmed on the basis of a thorough revision. Disarticulated, three-dimensionally preserved remains, mostly postcranial bones, from the Hauterivian - Early Barremian (Ruiz-Omeñaca et al. 2004) of the Galve region, in the central Iberian Range, were also referred to Eodiscoglossus santonjae by Estes and Sanchiz (1982). This assignment was based mainly on the presence of a projecting intercotylar process on the atlas, a feature that is also present on the atlas of one of the specimens from the type locality provisionally ascribed to the same species figured by Vergnaud-Grazzini and Wenz (1975, fig. 2); this material is now considered E. cf. santonjae (Sanchiz 1998). In turn, comparisons with the remains from Galve led Evans et al. (1990) to refer disarticulated bones from the Bathonian of England to the genus Eodiscoglossus Villalta, 1954, as a new species: E. oxoniensis EvAns, MiLner et MussetT, 1990. The generic identification was based on an overall phenetic resemblance, as well as the combination of some similarity to the ilium of the extant Discoglossus and the presence of presumable plesiomorphies. More recently, Sanchiz (1998) considered Neusibatrachus wilferti SEIFFERT, 1972 from the Santa Maria de Meià fossiliferous limestones, a junior synonym of Eodiscoglossus santonjae but a later study did not confirm this conclusion (Báez and Sanchiz 2007). In addition, a new reconstruction of E. santonjae based on the holotype was presented by Roček (2000), depicting some features that differ from earlier interpretations.

First-hand examination of the holotype of Eodiscoglossus santonjae at the Museo Nacional de Ciencias Naturales in Madrid (MNCN 4723, Text-fig. 1) revealed features that are in disagreement with the interpretation of most previous authors, as stated above. Hence, we considered it important to focus on some aspects of the anatomy of this species as a contribution that may assist in unraveling its taxonomic position as well as provide anatomical information that might help elucidate the evolutionary relationships of other basal taxa and shed light on the early diversification of crowngroup Anura.

The name Discoglossidae has been frequently applied to the group formed by the extant genera Alytes WAGLER, 1830, Bombina OKEN, 1816, Barbourula TAYlor et NoBle, 1924, and Discoglossus Oттн, 1837 (e.g., Noble 1931, Lynch 1973, Clarke 1988). However it has also been applied to the total group, including a presumably monophyletic crown and the fossil taxa placed at its stem (e.g., Duellman and Trueb 1985, Sanchiz 1998, Gao and Wang 2001, Gao and Chen 2004). These frogs belong to one of the earliest diverging anuran lineages (e.g., Roelants and Bossuyt 2005, Frost et al. 2006, Pyron and Wiens 2011) and are part of the group of taxa usually designated as "archaeobatrachians" because its members are perceived as "primitive" with respect to the more derived neobatrachians, which constitute the majority of the living anurofauna (Roelants and Bossuyt 2005). In the last decade, several cladistic and non-cladistic studies based on larval and adult morphological evidence have retrieved the monophyly of the group formed by the extant genera (e.g., Clarke 1988, 2007, Haas 2003) but no well-corroborated discoglossid adult morphological synapomorphies, potentially diagnostic, are so far known, as discussed below. However, other studies based on morphology-only cladistic analyses (e.g., Ford and Cannatella 1973) retrieved a paraphyletic Discoglossidae, with a clade formed by Bombina and Barbourula (Bombinatoridae) diverging earlier than the one formed by Alytes and Discoglossus (Discoglossidae sensu stricto or Alytidae of Frost et al. 2006). In turn, recent analyses based on molecular or combined molecular and morphological evidence support the monophyly of the group formed by Bombina, Alytes, and Discoglossus (Roelants and Bossuyt 2005, San Mauro et al. 2005, Frost et al. 2006, Pyron and Wiens 2011, Biton et al. 2013), the Costata of Frost et al. (2006), and the group also including Barbourula (Blackburn et al. 2010), but few morphological characters that unambiguously optimize on this branch have been discovered so far (Frost et al. 2006). With regard to the taxonomic framework, it should be noted that Discoglossidae is used as a stem-based name herein, unless stated otherwise. In fact, the characterization of the discoglossids has relied on a mosaic of several putative plesiomorphic plus a limited number of derived character states (e.g., Duellman and Trueb 1986, Roček 1994). This makes it difficult to clarify the identity and phylogenetic placement of several fossils that have been considered as belonging to this lineage, including those assigned to Eodiscoglossus santonjae.

\section{Systematic Palaeontology}

Anura Fischer [DE WALDHEIM], 1813

Eodiscoglossus Villalta, 1954

Type species: E. santonjae VILlaLtA, 1954

\section{E. santonjae Villalta, 1954}

H o lo ty p e: Articulated skeleton preserved as part and counterpart, inv. no. MNCN PV-4723 (Museo Nacional de Ciencias Naturales, Madrid).

L o c a lity: quarry near Rúbies, about $30 \mathrm{~km}$ north of Balaguer (fide Hecht 1970), Santa Maria de Meià, Lleida province, northeastern Spain.

Horizon: La Pedrera de Rúbies Lithographic Limestones Formation; the age of the limestones has been determined as Early Barremian (Ansorge 1995, MartínezClosas and López Morón 1995).

Emended diagnosis based on the holotype: Frog having a premaxillary with high, distally notched alary process; dentate maxillary arcade; quadratojugal extending along about $50 \%$ of pterygoid fossa; nasals in medial contact at least anteriorly; sphenethmoid exposed dorsally between nasals and frontoparietals; frontoparietals lacking supraorbital flanges; zygomatic ramus of squamosal not articulated with maxilla; pterygoid with robust anterior and posterior rami, the former articulating with maxilla at orbital midlength; angulosplenial with single bladelike coronoid 
process; eight presacral vertebrae; sacral diapophyses slightly expanded distally; short free ribs on vertebrae II-IV; scapula relatively short dorsoventrally and with straight leading margin; cleithrum non-forked at distal end; clavicle with long acuminate acromial end overlapping scapula anteriorly; carpus lacking torsion and with at least six free elements (probably "Morphology A" of Fabrezi 1992); prepollex hypertrophic with three elements and associated with epidermic pads; ilium relatively long, bearing a dorsal crest at least along the proximal (posterior) one third (the presence of a dorsal protuberance is uncertain); femur only slightly shorter than tibiofibula; proximal tarsals slightly more than half the length of tibiofibula.

Com ments: This emended diagnosis is based on the holotype, redescribed below; it consists of a combination of characters, most of which are common among "archaeobatrachians" and their evolutionary polarity is still ambiguous. The original diagnosis by Villalta (1954) included a few general features including the relatively short and wide skull, expanded sacral diapophyses, and bicondylar sacro-urostylar articulation; as discussed below, we consider that the latter two traits have been either misinterpreted or overinterpreted. Hecht (1970) also provided a diagnosis for E. santonjae (as a diagnosis for the genus, which was monotypic at that time) but the supposedly diagnostic absence of teeth on the maxillary arches of the holotype was subsequently denied by Vergnaud-Grazzini and Wenz (1975) and by us. The rest of his diagnostic features, presence of nuptial pads and columella, are insufficient to identify this species.

Annotated redescription of the type specimen: The only part of the holotype of this species available for examination consists of an articulated skeleton lacking most of the left hind limb, exposed in dorsal view. Some skeletal elements are preserved as impressions and others as fragmented bones; also evident are impressions of the body outline, eye pigments, and other soft-tissue structures (Text-fig. 1). The specimen has a total length of approximately $27.5 \mathrm{~mm}$; the well-ossified carpus and digits, including a robust prepollex formed by three elements and the impression of pads, indicate that it belongs to a postmetamorphic individual, probably a male.

The premaxillae are flipped anteriorly but it is clear that they bear well-developed, distally notched alary processes that were posterolaterally orientated when in natural position; other parts of these bones are poorly preserved (Text-fig. 2a). Anteriorly, the pars facialis of each maxilla seems to have overlapped the corresponding premaxilla, although the shape of the anterior terminus of the former bone is not discernable, whereas posteriorly the maxilla, when in natural position, articulated with the delicate quadratojugal. The latter element is clearly visible adjacent to the angulosplenial on both sides of the skull; it overlapped the maxilla for about $50 \%$ of the pterygoid fossa length (Text-fig. 2b). The left maxilla is flipped laterally exposing a regular series of triangular impressions along the anterior portion of its ventral margin (Text-fig. 2a); this suggests the presence of teeth, as was already noted by Vergnaud-Grazzini and Wenz (1975, pl. III, fig. 3). Likewise, impressions of dentate bones are discernable lateral to the nasals on both sides of the skull;

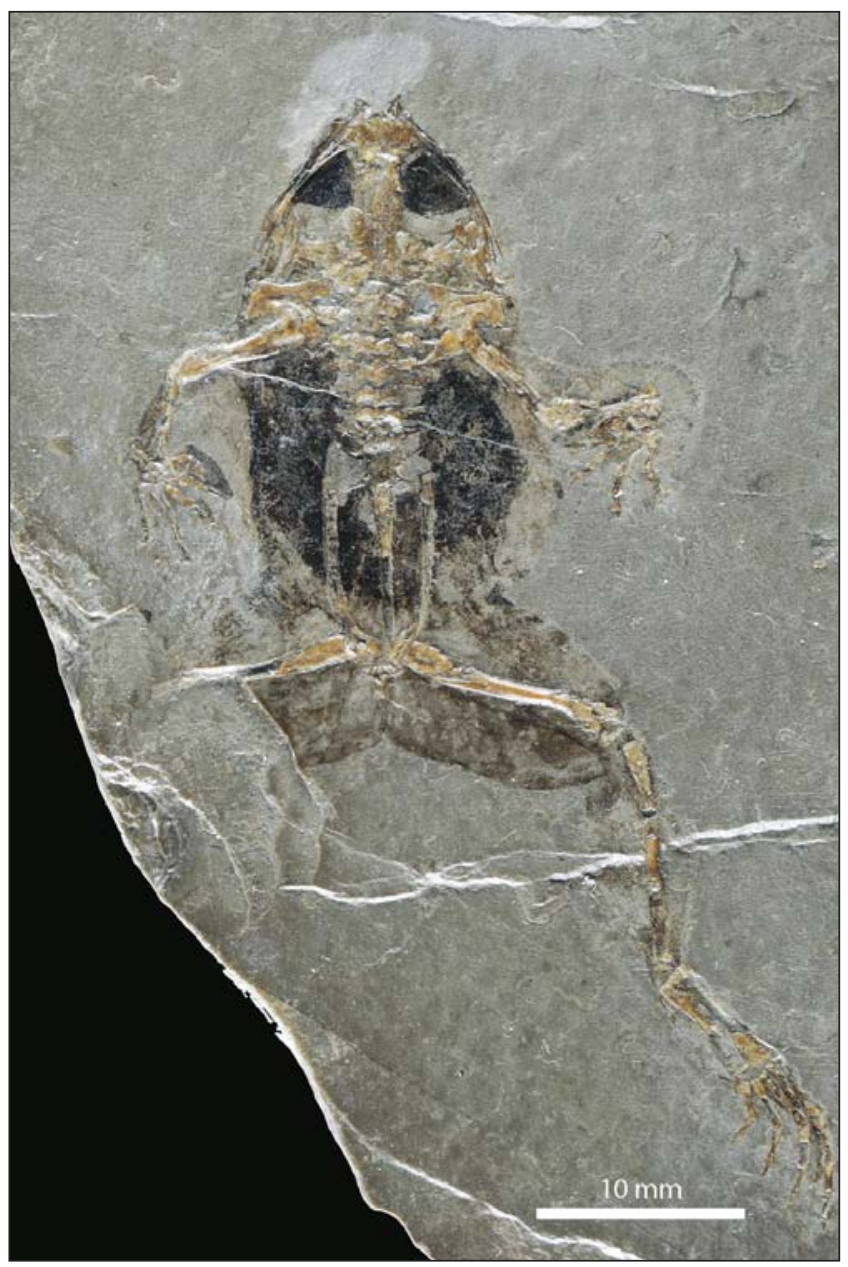

Text-fig. 1. Eodiscoglossus santonjae Villalta, 1954. General aspect of the holotype (MNCN 4723).

they correspond to the displaced vomers. Originally, Hecht (1970) had considered the maxillae as edentulous bones, a diagnostic feature of the species, a conclusion later provisionally accepted by Estes and Reig (1973). The maxillary pars facialis is moderately high anteriorly, diminishing in height along the orbit and becoming slightly higher posteriorly but lacking a zygomatic process. A distinct pars palatina with a rounded cross-section is visible in the left maxilla, but other features in this aspect are not discernable. The nasals, preserved mostly as impressions, are extensive and in contact with one another along the midline anteriorly whereas posteriorly they appear slightly separated; their overall shape, however, is difficult to reconstruct due to poor preservation. A midline contact between the nasals was considered by Dong et al. (2013) to be lacking in E. santonjae. The anterior margin of each nasal has a shallow indentation next to a narrow, well-defined rostral process; this indentation probably marks the location of the external nare in life; a well-defined maxillary process appears to be absent. Posteriorly, the nasals are separated from the frontoparietal by the sphenethmoid, which is exposed dorsally. The sphenethmoid, whose paired or single condition is not clear, circumscribes the anterior margin of the frontoparietal fenestra. The frontoparietals are incompletely preserved and crushed against the cavum cranii, precluding description of their overall configuration. A median suture is 


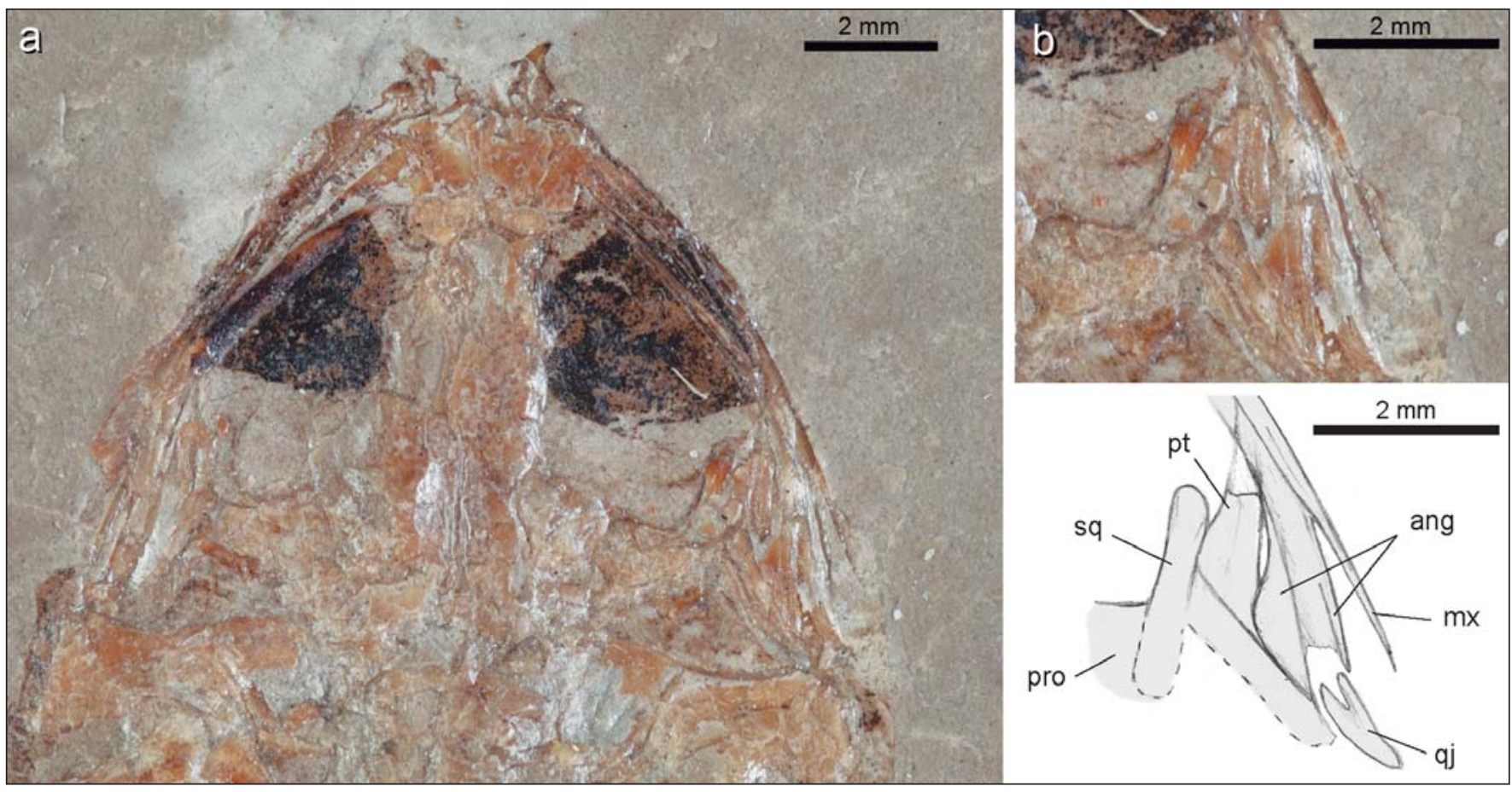

Text-fig. 2. Eodiscoglossus santonjae VILLALTA, 1954. Holotype (MNCN 4723), a: aspect of the skull; b: Close-up of the right suspensorial region, with interpretive drawing below. Abbreviations: ang - angulosplenial; mx - maxilla; pro - prootic; pt - pterygoid; qj - quadratojugal; sq - squamosal.

not evident, although this might be the consequence of postmortem crushing; this is probably why Hecht (1970) described the frontoparietal as if it were azygous. In contrast, Estes and Reig (1973) figured the frontoparietals as paired bones in contact along the midline for most of their lengths. Biton et al. (2013) also scored the frontoparietals as paired in Eodiscoglossus even though their cited source of information for this taxon does not include the configuration of this bone. A short anterior fontanelle formed by the divergent anteromedial margins of the frontoparietals might be present, but it is clear that at least in the posterior orbital region these bones roofed the braincase completely. The lateral margins of the frontoparietals are slightly divergent posteriorly; supraorbital flanges are absent. The presence and shape of posterolateral expansions investing the epiotic eminences are unknown due to breakage on both sides of the skull. The outline of the posterior margins of the frontoparietals, located slightly anterior to the foramen magnum, is not clearly discernible. The dorsal surface of the frontoparietal is shallowly pitted, as is that of the few preserved bony fragments of the nasals. The prootics and exoccipitals form the otic capsules, although the crushed condition of this part of the skull prevents confident assessment as to whether these bones were fused. The T-shaped squamosals are preserved on both sides of the skull. The free-ending zygomatic ramus seems to be somewhat shorter than the otic ramus, whereas the ventral ramus is the longest of the three rami of the bone. There is no evidence of contact between the zygomatic ramus of the squamosal and the maxilla (Text-fig. 2a, b) as depicted in the restoration based on the holotype by Roček (2000), whereas this contact was scored as absent in the genus by Biton et al. (2013). The well-ossified pars media plectri is clearly visible between the otic capsule and the squamosal, presumably applied to the oval foramen on the left side of the skull, whereas the contralateral element is isolated and poorly preserved. The plectrum has a robust shaft and a slightly expanded footplate. The pterygoid is partially visible ventral to the squamosal; the anterior ramus of this palatal bone is relatively wide and articulates with the maxilla at the level of the midlength of the orbit. Each half of the lower jaw is composed of an angulosplenial and dentary; the presence of a mentomeckelian cannot be determined because the anterior part of the mandible disappears under the nasals. The angulosplenial has a dorsally open Meckelian groove (Text-fig. 2b) and a single well-developed, laminar coronoid process exposed on the right bone (see also Hecht 1970, fig. 3), contra the opinion of Roček (1994) who considered the coronoid process as absent. The articulation for the mandible is located at almost the level of the occiput.

The axial skeleton is composed of eight presacral vertebrae, a single sacral vertebra, and the urostyle. The type of articulation between successive vertebrae cannot be determined; in this regard we agree with Hecht (1970) and Estes and Reig (1973) but not with Gao and Wang (2001) who considered that the opisthocoelous condition of the last three presacrals can be ascertained in this specimen. The atlantal neural arch has a straight anterior margin and lacks transverse processes; on the right side, the ventrally directed pedicle projects laterally suggesting that the cotyles for the occipital condyles were transversely elongated and with axes forming a shallow angle and thus mostly located ventral to the neural canal. The following three presacrals (II, III, and IV) have distally expanded transverse processes that articulate with short ribs; the most anterior pair of these processes is slightly anteriorly directed whereas the succeeding two pairs are laterally orientated. The ribs that articulate with Vertebra III are the longest; these ribs as well 


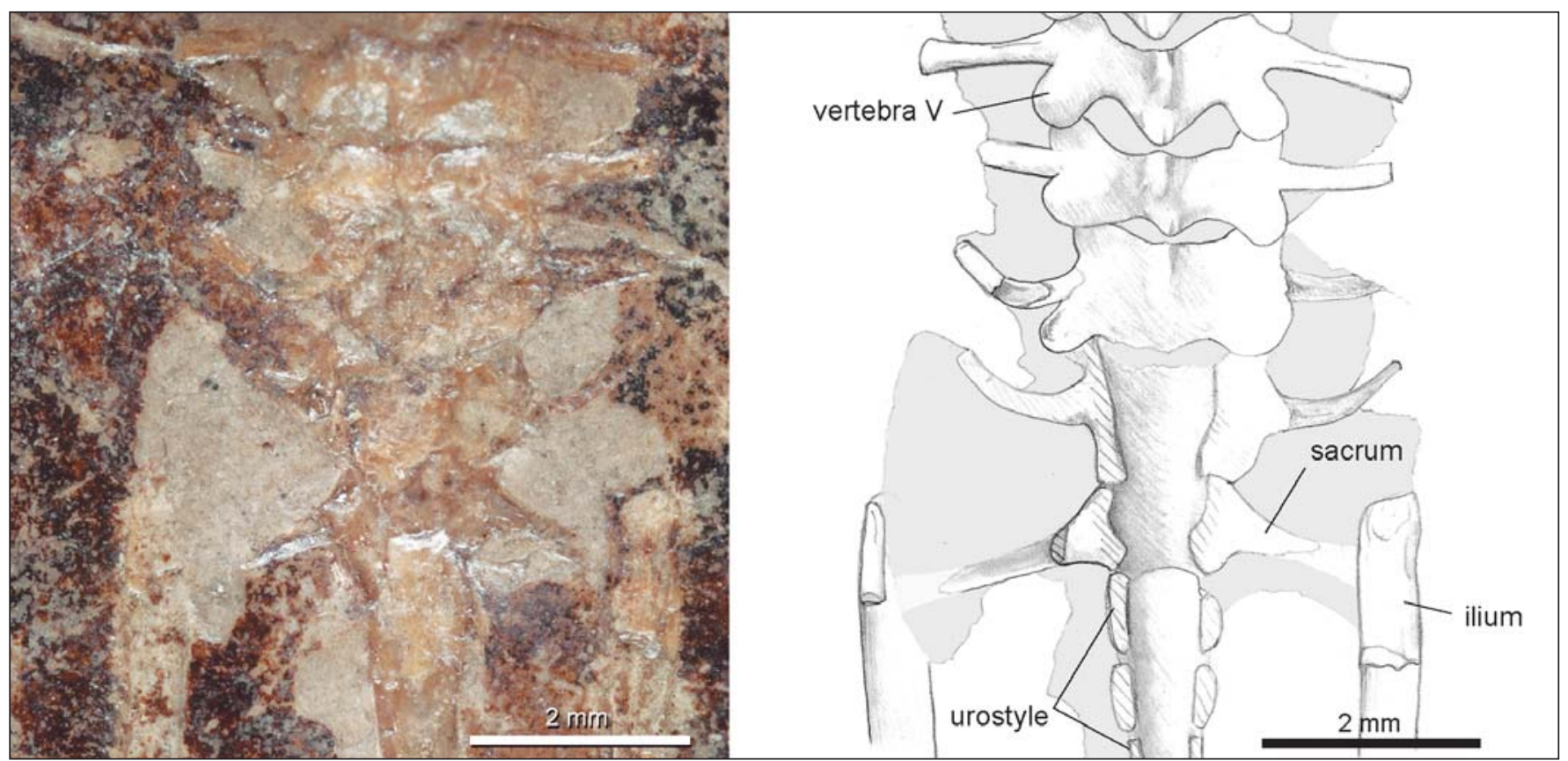

Text-fig. 3. Eodiscoglossus santonjae VillaLta, 1954. Holotype (MNCN 4723), close-up of posterior presacral vertebrae and sacral region, with interpretive drawing.

as those on Vertebra IV are expanded proximally and distally but the proximity of the clavicles partially obscures observation of the distal ends of the most anterior pair of ribs. The four succeeding vertebrae (presacrals V to VIII) have short transverse processes with blunt distal ends that might have terminated in cartilage. The most anterior pair of these processes is nearly perpendicular to the longitudinal axis of the vertebral column, the following pair is slightly anteriorly directed, and the two most posterior ones are distinctly anteriorly directed forming a relatively wide angle with respect to the axis of the vertebral column. The medial regions of the neural arches of vertebrae II to $\mathrm{V}$ project posteriorly into spinous processes that reach the respective succeeding vertebra, whereas the posterior margins of the arches on both sides of the processes are markedly concave, as also shown by Hecht (1970), with oval patches of sediment posterior to these concavities that partially obscures the anterior margin of the corresponding succeeding vertebra (Text-fig. 3). This suggests that the neural canal might have been partially exposed dorsally (contra Estes and Reig 1973 who depicted the neural arches strongly imbricated). The neural arches of vertebrae VI and VII are incompletely preserved; fine longitudinal ridges along the midline borne by vertebrae V and VI are clearly visible. The neural arches of the last presacral (VIII) and sacral vertebra (IX) are missing whereas their respective centra are only represented by scraps of bone. The interpretation of the configuration of the sacral diapophyses is confusing due to distinct hatchet-shaped, whitish areas that are in contact with the ilia (Text-fig. 3). Areas of similar color however also occur near the transverse processes along the vertebral column and might be due to the deposits in the endolymphatic system related to the maintenance of the acid-base homeostasis, as suggested by Hecht (1970, see also Warren and Jackson
2005). Shallow impressions of posteriorly deflected, proximally narrow and slightly distally expanded diapophyses that reach the corresponding ilia are clearly discernible on both sides. Moreover, illustrations of this region under polarized light (Hecht 1970) were interpreted to depict narrow sacral diapophyses preceded by an artifact of preservation contra to the opinion of Villalta (1954) and Gao and Wang (2001) who scored the sacral diapophyses of this taxon as expanded. The anterior portion of the urostyle is longitudinally sectioned whereas its posterior two thirds are preserved as an impression of the round cross-sectioned hypochord. At the anterior part of the urostyle one pair of irregular swellings on each side of the bone suggests the participation of a pair of postsacral neural arches in the formation of the coccyx. Transverse processes and a dorsal crest are not discernible on the urostyle, as noted previously by Hecht (1970).

Components of the pectoral girdle are exposed in dorsal aspect. The cleithrum is a well-developed, elongate bone that formed a groove for the anterior margin of the suprascapular cartilage (Text-fig. 4). The available evidence does not support the extensive, bifurcated cleithrum depicted by Estes and Reig (1973). Loss of the proximal part of this bone on the right side has exposed the scapula, whereas the anterior shifting of the left cleithrum has made part of the scapula visible on this side. The scapula has a straight leading edge due to the presence of an anterior crest that extends from the pars acromialis to the suprascapular margin; the dorsoventral width of the shaft is similar to that of the glenoidal region. The acromial and glenoidal parts are nearly equally developed and they appear to be separated by a medial (ventral) notch. The glenoidal ends of the clavicles are visible on both sides; right and left clavicles have long, tapering ends that must have been broadly articulated with the respective 


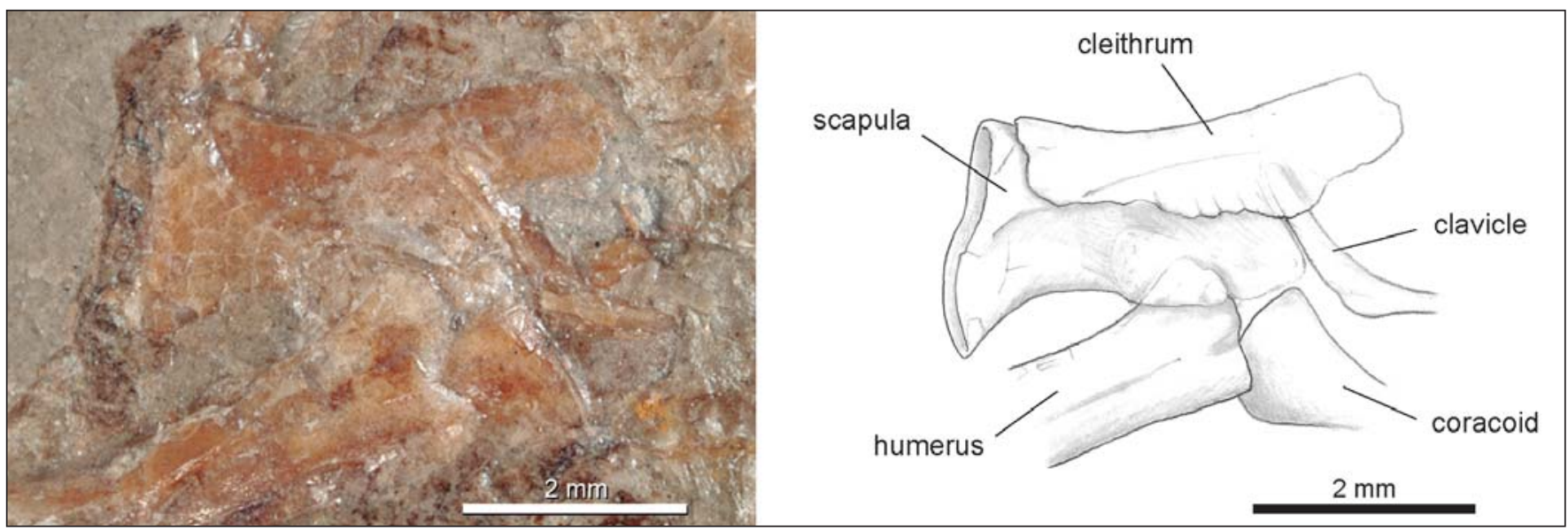

Text-fig. 4. Eodiscoglossus santonjae Villalta, 1954. Holotype (MNCN 4723), close-up of left half of pectoral girdle with interpretive drawing.

pars acromialis of the scapula (Text-fig. 4). The dorsal ends of both coracoids are preserved; they are expanded with a relatively narrow diaphysis. The ventral halves of the bones disappear beneath the axial column but it is clear that their long axes were posteromedially directed. The humerus is robust and bears a well-developed ventral ball; an ample deltoid crest extends along the proximal half of the humeral length. Impressions of several carpal elements are preserved in both forelimbs. The proximal row is composed of two large bones that are in contact with the radioulna; these are the radiale and ulnare respectively. Distal to the former bone, the impression of Element $\mathrm{Y}$ is visible, whereas distal to the ulnare there is another large element that probably corresponds to the Distal Carpal 5. On the preaxial side of the latter and next to the base of Metacarpal IV, a smaller bone might be identified as Distal Carpal 4. Another distal carpal, probably Distal Carpal 3, appears between the bases of metacarpals II and III. A hypertrophied prepollex that is composed of three elements is clearly visible on the preaxial side of Element Y. The metacarpals are proximally and distally expanded. The phalangeal formula is $2-2-3-3$, the digital lengths (in ascending order) being $\mathrm{II}<\mathrm{III}<\mathrm{V}<\mathrm{IV}$. The terminal phalanges have elongate, narrow distal ends.

The ilia and ischia are the only visible components of the pelvic girdle. The ilia are preserved mostly as imprints. The iliac shaft bears a narrow dorsal crest that is broader along the proximal (posterior) third of the shaft length. The ischia are fused to one another. Other features of the pelvic girdle are not clearly visible owing to the position in which this skeletal part is exposed. The femur is distinctly sigmoid and slightly shorter than the tibiofibula; a femoral crest is not discernible. The tibiale and fibulare are fused proximally and distally; their lengths represent about $57 \%$ the length of the tibiofibula. A tiny triangular prehallical element is visible next to the wide base of Metatarsal I and on the preaxial side of a slightly larger tarsal bone that can be identified as Element Y. Other distal tarsals are not preserved indicating that they might have been cartilaginous. The phalangeal formula is $2-2-3-4-3$. The terminal phalanges are long and have simple distal ends.

\section{Other specimens from the type locality referred to E. santonjae}

As noted earlier, several specimens from the type locality but from two different fossiliferous levels were described by Vergnaud-Grazzini and Wenz (1975) and referred provisionally to Eodiscoglossus santonjae, whose holotype had been thoroughly described previously by Hecht (1970) and later briefly by Estes and Reig (1973). VergnaudGrazzini and Wenz (1975) considered that all these specimens were discoglossids owing to the presence of at least three of the following features in each specimen: 1) eight, probably opisthocoelous, presacral vertebrae; 2) free ribs on vertebrae II-IV; 3) biconvex sacral vertebrae, with two posterior condyles; 4) one pair of transverse processes on the urostyle; 5) short scapula, apparently lacking a medial notch; and 6) dentate maxillary arches and vomers. These authors also concluded that, despite the different sizes and proportions, all these specimens belong to the same species. They also attributed the difference in disposition of the different elements to postmortem deformation. These conclusions were subsequently tacitly accepted by other authors and comments either on Eodiscoglossus or E. santonjae as well as scoring for these taxa have been based on the evidence provided by this collection of specimens (e.g., Evans et al 1990, Gao and Wang 2001, Biton et al. 2013). Moreover, the diagnosis of the genus by Evans et al. (1990) includes the count of premaxillary and maxillary teeth not discernible in the holotype of the type species.

Independently from the validity of each of these characters and/or their combination to diagnose this anuran lineage, it is pertinent to evaluate the evidence for the referral of all or some of these specimens to E. santonjae. Comparisons, however, are problematic because these specimens are preserved in aspects different from the holotype, thereby exposing different bones, the lack of apomorphic characters in the holotype to avoid plesiomorphic phenetic resemblance, and the different ontogenetic stages to which all these specimens belong. Despite these shortcomings, and considering size as a proxy for the developmental stage, firsthand examination of some of these specimens makes it possible to point out some morphological and comparative features. 
Specimens MNHN MSE 1 and MSE 3a, b belong to individuals smaller (their total lengths are estimated as about 16 and $21 \mathrm{~mm}$, respectively) and younger than the holotype of E. santonjae. The former, exposed in ventral aspect, has the shallow impression of a short tail, the hypochord is still not synostotically fused to the coccyx, and the terminal phalangeal elements are not ossified; it probably belongs to a metamorphosing individual. MSE $3 \mathrm{a}$ and $\mathrm{b}$ belong to an individual preserved mostly ventrally, the premaxillary and maxillary teeth are pedicellate, the vertebral column is lacking the centra, which seem to have been weakly united to the well-developed pedicles. We did not find any feature preserved in these two specimens that would make their referral to $E$. santonjae questionable, although a few similarities can be ascertained apart from the elongate, notched alary processes borne by the premaxillae, the dentate condition of the maxillary arches and the vomers, presence of distally expanded free ribs in vertebrae II-IV, anteriorly directed and relatively short transverse processes on the last three presacrals, and slightly expanded sacral diapophyses.

Specimen MNHN MSE 2 is from a slightly lower level than the holotype-bearing horizon (Vergnaud-Grazzini and Wenz 1975); it most likely belongs to an adult that had a total length about twice that of the holotype. The partially articulated skeleton, exposed in ventral view, is incomplete; some elements such as the distal portion of the urostyle and parasphenoid alae are somewhat covered by sediment so they are not as short as depicted by Vergnaud-Grazzini and Wenz (1975). The vertebral column is composed of eight presacrals that show the scars of the recent synostotic fusion of pedicles and centra. There is also partial fusion of the expanded ends of ribs and transverse processes borne by vertebrae II-IV. The centra of vertebrae II-VIII are longer than they are wide and strongly protuberant and probably with a rounded cross section at the level of articulation with adjacent vertebrae; the nature of these articulations is not discernable. Few elements can be compared with the same elements in the holotype. The atlantal centrum bears cotyles closely spaced and with axes forming a wide, obtuse angle. The sacral vertebra bears posteriorly slanted, moderately expanded diapophyses whose distal lengths are about twice their proximal lengths. A shallow groove at the posterior end of the sacral centrum is the only indication that a bicondylar articulation between sacrum and urostyle might have existed. The leading margin of the scapula is broken; partes acromialis and glenoidalis are well developed and separated by a shallow notch. The extended ventral contribution of the sphenethmoidal ossification to the floor of the nasal capsules, the long cultriform process of the parasphenoid, the ventrally directed flange along the anterior ramus of the pterygoid, as well as the partially fused ribs and transverse processes might be due to the probable advanced age of this individual. Transverse processes of vertebrae VII-VIII are short but horizontally orientated, unlike the anteriorly orientated processes of these vertebrae in MSE 1, 3, and MNCN 4723.

MNHN MSE 5 is preserved as disarticulated bones; the tibiofibula is about $12 \mathrm{~mm}$ long, i.e. nearly the same length as that of MNCN 4723, so we assume that it belongs to an individual of about the same total length. Left and right ilia are relatively well preserved and exposed in acetabular or slightly dorsolateral aspect, although the most anterior

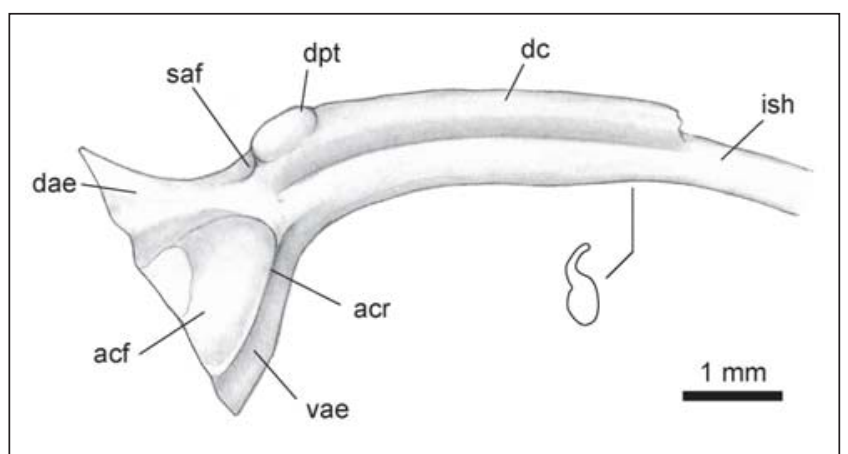

Text-fig. 5. MNHN MSE 5. Drawing of right ilium in dorsolateral view with reconstructed cross section. Abbreviations: acf - acetabular fossa; acr - acetabular rim; dae - dorsal acetabular expansion; dc - dorsal crest; dpt - dorsal protuberance; ish iliac shaft; saf - supraacetabular fossa; vae - ventral acetabular expansion.

portions of the shafts are missing in both elements (Text-fig. $5)$. In each bone, the main portion of the shaft has an oval cross-section; a depression separates this portion from a dorsal crest whose distal half is distinctly deflected medially. Slightly anterior to the level of the anterior margin of the acetabulum, a distinct oval dorsal protuberance occurs on the dorsal crest projecting slightly from its dorsal margin. Posterior to the protuberance, is a marked oval depression previously described as a supraacetabular fossa (the latter fossa was erroneously identified as a depression dorsal to the acetabulum in E. oxoniensis by Evans et al 1990; see also Gómez and Turazzini 2015). The acetabulum is clearly demarcated ventrally by a moderately developed rim that does not reach the ventral margin of the bone, whereas dorsally it is less defined. There is a broad dorsal acetabular expansion but posteriorly it does not project beyond the dorsal margin of the shaft (Text-fig. 5).

MNHN MSE 6 is an articulated, partially preserved specimen (Vergnaud-Grazzini and Wenz 1975, pl. III, fig. 4). Only part of the postcranial skeleton, mostly in dorsal view, is present; it belongs to an adult individual about twice the size of MNHN 4723, estimated according to the lengths of femur and tibiofibula (22 $\mathrm{mm}$ and $24 \mathrm{~mm}$, respectively). The posteriormost six presacral vertebrae (III-VIII?) are exposed in dorsal view although only their right sides are preserved; no free ribs are discernable. The longest transverse processes are those on the two most anterior vertebrae, especially the one borne by Vertebra III. The following two vertebrae have posteriorly directed transverse processes, whereas the two last presacrals have anteriorly directed processes. The sacral vertebra has narrow, posteriorly directed diapophyses. The long disarticulated urostyle $(18.5 \mathrm{~mm})$ is exposed on its right side; along the anterior two thirds of its length it bears a dorsal spinous process whose height diminishes posteriorly. Anteriorly this process is as high as the ventral part of the bone; transverse processes are not discernable. The ischia have rounded posterior margins and are not fused to one another. The left ilium is exposed in medial view whereas the contralateral element is visible in acetabular view. The morphology of this bone is similar to that of MSE 5 described above and we consider that these two specimens represent the same species. However, based on the morphology and 
orientation of the presacral transverse processes and the shape of the sacral diapophyses, MSE 6 is not referable to the taxon represented by MSE 2, an adult of about the same total length and, thus, wholly comparable with it.

In summary, the holotype of E. santonjae was probably an adult male, as inferred by the hypertrophied prepollex and the associated nuptial pads (Hecht 1970). Only a few features included in the diagnosis presented herein can be ascertained in each of the specimens reviewed above. However, none of these features unequivocally diagnoses this species, as most have been described in other taxa and many are probable plesiomorphic. Moreover the probable presence of more than one taxon in this sample aggravates this problem. Therefore, the taxonomic allocation of these specimens awaits critical comparison with other material, especially that of Mesozoic age and ascribed to "Discoglossidae".

\section{The Phylogenetic Position of $E$. santonjae}

Since its discovery, the holotype of Eodiscoglossus santonjae, type species of the genus, has been considered to represent a discoglossid species (e.g., Villalta 1954, Hecht 1970, Estes and Reig 1973). This taxonomic placement was based mainly on the presence of eight, supposedly opisthocoelous presacral vertebrae, free ribs on presacrals II-IV, and allegedly imbricate neural arches. However, from the foregoing description it is clear that the opisthocoelous nature of the vertebral centra cannot be unambiguously assessed, free ribs are plesiomorphic at this level of generality, and the neural canals are dorsally partially exposed in this specimen. Acceptance of the referral of several additional specimens to E. santonjae (Vergnaud-Grazzini and Wenz 1975), as noted above, added other "discoglossid" features, particularly those present in the Discoglossus group. Hence, some authors emphasized that E. santonjae might be more closely related to species of Discoglossus than to other living discoglossids, based mainly on the shared presence of a dorsal crest and an elongated dorsal protuberance on the ilium (Estes and Sanchiz 1982, Evans et al. 1990, Roček 2000). Although not common amongst "archaeobatrachians", a well-developed dorsal crest on the iliac shaft is present in some Early Cretaceous pipimorphs (Jones et al. 2003, Báez 2013) whereas it also occurs in several groups of neobatrachians, implying that this structure might have arisen independently several times in anuran history. In addition, it is noteworthy that if E. santonjae is closer to Discoglossus than to Alytes, the lineages represented by these extant taxa must have diverged at least earlier than the appearance of E. santonjae in the Barremian, but this is at odds with several recent estimates that position this divergence later in the Cretaceous (Wiens 2007, Blackburn et al. 2010, Ruane et al. 2011, Gómez-Mestre et al. 2012).

Most discussions of the taxonomic position of Eodiscoglossus have been based on the results of parsimony analyses in which the scoring for this taxon was probably composite and without an explicit and critical examination of the content of the genus. The position was first tested in a cladistic context by Wang et al. (2000) by including Eodiscoglossus as a terminal taxon in their examination of discoglossid interrelationships, incorporating some extinct taxa in the analysis largely based on the data matrix of Báez and Basso (1996). They recovered Eodiscoglossus as sister to crown-group Discoglossidae, a relationship supported by two synapomorphies of the pectoral girdle: coracoid with limited expansion anteromedially and forked cleithrum. The former condition is common amongst frogs, even in groups that were not included in their analysis such as pipoids and many neobatrachians. Based on our interpretation of the holotype of E. santonjae, the presence of a forked cleithrum in this species is unwarranted, whereas the condition in the putative Jurassic member of the genus E. oxoniensis is unknown (Evans et al. 1990). Subsequently, Eodiscoglossus was incorporated in the similarly conducted cladistic analyses by Gao and Wang (2001), Gao and Chen (2004), and Wang (2006), also emerging as a member of the discoglossid lineage. Among these studies, in the only analysis in which a discussion of the synapomorphies supporting the discoglossid node is accessible to us (Gao and Wang 2001) this relationship is justified by the following features: vomer bearing a postchoanal process that forms a narrow angle with the anterior part of the bone, presence of anterior overlap of clavicle on scapula, coracoid little expanded medially, and trigeminal and facial foramina separated by the prefacial commissure. However, some of these features have been erroneously scored in several of their terminal taxa. In addition, in the case of Eodiscoglossus, the entire set of character-states for this genus does not agree with those of any of the species that have been included in the genus. For example, Gao and Wang (2001) scored several features according to their interpretation of a photograph of the holotype of E. santonjae, such as the expanded sacral diapophyses and the poorly developed iliac dorsal tubercle, even though in other specimens attributed to the species that they used for scoring other features the condition is different. More recently, Eodiscoglossus has been included as a terminal taxon in the phylogenetic analyses of Dong et al. (2013) and Báez (2013) based on morphological traits, of which only in the latter was the scoring based exclusively on the holotype of E. santonjae. The results of these analyses deviated to some extent from previous hypotheses regarding the systematic position of this taxon. The reanalysis of the published data matrix of Dong et al. (2013) with TNT v. 1.5-beta resulted in 16 most parsimonious trees (MPTs) of 178 steps, the strict consensus of which is identical with the tree depicted by these authors (Dong et al. 2013, fig. 8). A monophyletic Discoglossidae is not recovered in the majority of these MPTs, whereas Eodiscoglossus and extant discoglossids occur in a polytomy that also includes a clade containing pipoids and pelobatoids. In contrast, Báez (2013) did obtain a monophyletic Costata sensu Frost et al. (2006) and recovered $E$. santonjae as sister group of Lalagobatrachia (i.e., all anurans other than leiopelmatids sensu Frost et al. 2006). In her analysis, the latter clade is supported by two putative synapomorphies, sacral diapophyses moderately expanded and cleithrum forked, which occur in the respective plesiomorphic conditions in the holotype of E. santonjae. Additionally, most putative synapomorphies of the crown group are either in their plesiomorphic states or undeterminable in the holotype of E. santonjae. In turn, Biton et al. (2013) scored 22 skeletal characters for several extinct and extant putative discoglossid taxa, including Eodiscoglossus, the scoring for which was obviously based on all the 
specimens previously assigned to the genus. The Bayesian tree, based on three mitochondrial and three nuclear genes and the morphological characters, was rooted on Ascaphus truei STEJNEGER, 1899 placing Eodiscoglossus as sister to the clade that includes Alytes and Discoglossus as well as several extinct taxa. It is noteworthy, however, that this analysis did not test the inclusion of all these extinct taxa as members of the discoglossid lineage as only discoglossids are considered with the exception of Ascaphus.

A phylogenetic placement of Eodiscoglossus santonjae crownward to leiopelmatiids but outside Lalagobatrachia clearly explains its overall plesiomorphic morphology, including the configuration of the skull, eight presacrals, free ribs, atlantal cotyles horizontally orientated, sacrum with poorly expanded diapophyses, relatively short scapula with a straight leading margin, narrow cleithrum, generalized proportions of the limbs, and carpus lacking torsion. This position is also consistent with the estimated divergent times for Anura, Lalagobatrachia, and crown-group Discoglossidae based either on some molecular clock methods or the paleontological record (Blackburn et al. 2010, San Mauro 2010, Ruane et al. 2011, Marjanović and Laurin 2014). However, the monophyly of the genus has not yet been unambiguously corroborated, although it has been used as a calibration point that serves as a minimum boundary for the clade Lalagobatrachia (e.g., Ruane et al. 2011), or even for the crown-group Discoglossidae (Blackburn et al. 2010; Costata therein), thus directly impinging on the estimated ages of these clades. To exemplify this point, Blackburn et al. (2010) obtained an estimated divergence time for Costata 25 million years younger by removing this single calibration point.

From the foregoing, we consider being as explicit and conservative as possible in evaluating the systematic placement of fossil taxa such as E. santonjae to be of the utmost importance. Given that the placement of this taxon is not unambiguously resolved at present and that a full revision of the Jurassic and Cretaceous specimens already ascribed to this genus is still pending (Estes and Sanchiz 1982, Evans et al. 1990, Báez 2013), at this point we regard Eodiscoglossus as Anura incertae sedis.

\section{Acknowledgements}

The authors are pleased to honor the valuable work of Dr. Z. V. Špinar on fossil frogs. They express their thanks to Celia M. Santos and Borja Sanchiz (Museo Nacional de Ciencias Naturales, Madrid), and Damien Germain (Museum National d'Histoire Naturelle, Paris) for the loan of fossil material in their care. Thanks are also extended to Jesús Muñoz and Borja Sanchiz (Museo Nacional de Ciencias Naturales, Madrid) for the photographs of the holotype of Eodiscoglossus santonjae. This work was funded by the Agencia Nacional de Promoción Científica de Argentina, PICT 1895/2011. We are grateful to the reviewers, Márton Venczel (Țării Crişurilor Museum, Oradea) and Yuan Wang (Chinese Academy of Sciences, Beijing), for their valuable comments and to Jan Wagner (National Museum, Prague) for his careful editorial work.

\section{References}

Ansorge, J. (1993): Bemerkenswerte Lebensspuren und ?Cretosphex catalunicus n. sp. (Insecta; Hymenoptera) aus den unterkretazischen Plattenkalken der Sierra del Montsec (Provinz Lerida, NE - Spanien). - Neues Jahrbuch für Geologie und Paläontologie, 190: 19-35.

Báez, A. M. (2013): Anurans from the Early Cretaceous Lagerstätte of Las Hoyas, Spain: New evidence on the Mesozoic diversification of crown-clade Anura Cretaceous Research, 41: 90-106. http://dx.doi.org/10.1016/j.cretres.2012.11.002

Báez, A. M., Basso, N. (1996): The earliest known frogs from the Jurassic of South America: review and cladistic appraisal of their relationships. - In: Arratia, G. (ed.), Contributions of southern South America to vertebrate paleontology. Münchner Geowissenschaftliche Abhandlungen, Reihe A, Geologie und Paläontologie, 30: 131-158.

Báez, A. M., Moura, G. J. B., Gomez, R. O. (2009): Anurans from the Lower Cretaceous Crato Formation of northeastern Brazil: implications for the early divergence of neobatrachians. - Cretaceous Research, 30: 829-846. http://dx.doi.org/10.1016/j.cretres.2009.01.002

Báez, A. M., Sanchiz, B. (2007): A review of Neusibatrachus wilferti, an Early Cretaceous frog from the Montsec Range, northeastern Spain. - Acta Palaeontologica Polonica, 52: 477-487.

Biton, R., Geffen, E., Vences, M., Cohen, O., Bailon, S., Rabinovich, R., Malka, Y., Oron, T., Boistel, R., Brumfelt, V., Gafny, S. (2013): The rediscovered Hula painted frog is a living fossil. - Nature Comunications, 4: 1959. doi 10.1038/ncomms 2959 http://dx.doi.org/10.1038/ncomms2959

Blackburn, D. C., Bickford, D. P., Diesmos, A. C., Iskandar, D. T., Brown, R. M. (2010): An ancient origin for the enigmatic flat-headed frogs (Bombinatoridae: Barbourula) from the islands of Southeast Asia. - PLoS ONE, 5: $1-10$. http://dx.doi.org/10.1371/journal.pone.0012090

Clarke, B. T. (1988): Evolutionary relationships of the discoglossoid frogs - Osteolological evidence; Ph.D. Thesis. - MS, British Museum of Natural History and City of London Polytechnic, London, Great Britain, 431 pp. (copy in The British Library Document Supply Centre)

Clarke, B. T. (2007): Comparative Morphology and Amphibian Taxonomy: an example from the Osteology of the Discoglossoid Frogs. - In: Heatwole, H., Tyler, M. (eds), Amphibian Biology, Surrey Beatty and Sons, Chipping Norton, pp. 2465-2612.

Dong, L., Roček, Z., Wang, Y., Jones, M. E. H. (2013): Anurans from the Lower Cretaceous Jehol Group of Western Liaoning, China. - PloS ONE, 8(7): e69723. http://dx.doi.org/10.1371/journal.pone.0069723

Duellman, W. E., Trueb, L. (1986): Biology of Amphibians. - McGraw-Hill Inc., New York, 670 pp.

Estes, R., Reig, O. A. (1973): The early fossil record of frogs: a review of the evidence. - In: Vial, J. L. (ed.), Evolutionary Biology of the Anurans. Contemporary Research on Major Problems, University of Missouri Press, Columbia, pp. 11-36. 
Estes, R., Sanchiz, B. (1982): Early Cretaceous lower vertebrates from Galve (Teruel), Spain. - Journal of Vertebrate Paleontology, 2: 21-39. http://dx.doi.org/10.1080/02724634.1982.10011915

Evans, S. E., Milner, A. R., Mussett, F. (1990): A discoglossid frog from the Middle Jurassic of England. - Palaeontology, 33: 299-311.

Fabrezi, M. (1992): El carpo de los anuros [The anuran carpus]. - Alytes, 10: 1-29. (in Spanish)

Fischer [de Waldheim], G. (1813): Zoognosia tabulis synopticis illustrata, in usum prælectionum Academiæ Imperialis Medico-Chirurgicæ Mosquensis edita. $3^{\text {rd }}$ ed. Vol. 1. - Nicolai Sergeidis Vsevolozsky, Mosquae, 465 pp.

Ford, L. S., Cannatella, D. C. (1993): The major clades of frogs. - Herpetological Monographs 7: 94-117. http://dx.doi.org/10.2307/1466954

Frost, D. R., Grant, T., Faivovich, J., Bain, R. H., Haas, A., Haddad, C. F. B., de Sá, R. O., Channing, A., Wilkinson, M., Donnellan, S. T., Raxworthy, C. J., Capbell, J. A., Blotto, B. L., Moler, P., Drewes, R. C., Nussbaum, R. A., Lynch, J. D., Green, D. M., Wheeler, W. C. (2006): The Amphibian Tree of Life. - Bulletin of the American Museum of Natural History, 297: 1-370. http://dx.doi.org/10.1206/0003-0090(2006)297 [0001:TATOL]2.0.CO;2

Gao, K.-Q., Chen, S. (2004): A new frog (Amphibia: Anura) from the Lower Cretaceous of western Liaoning, China. - Cretaceous Research, 25: 761-769. http://dx.doi.org/10.1016/j.cretres.2004.06.011

Gao, K.-Q., Wang, Y. (2001): Mesozoic anurans from Liaoning Province, China, and phylogenetic relationships of archaeobatrachian anuran clades. - Journal of Vertebrate Paleontology, 21: 460-476.

http://dx.doi.org/10.1671/0272-4634(2001)021 [0460:MAFLPC]2.0.CO;2

Gómez, R. O., Turazzini, G. F. (2015): An overview of the ilium of anurans (Lissamphibia, Salientia), with a critical appraisal of the terminology and primary homology of main ilial features. - Journal of Vertebrate Paleontology, 36(1): e1030023 (12 pages). http://dx.doi.org/10.1080/02724634.2015.1030023

Gómez-Mestre, I., Pyron, R. A., Wiens, J. J. (2012): Phylogenetic analyses reveal unexpected patterns in the evolution of reproductive modes in frogs. - Evolution, 2012: 3687-3699 (and supporting information). http://dx.doi.org/10.1111/j.1558-5646.2012.01715.x

Haas, A. (2003): Phylogeny of frogs as inferred from primarily larval characters (Amphibia: Anura). - Cladistics, 19: 23-89. http://dx.doi.org/10.1016/s0748-3007(03)00006-9

Hecht, M. K. (1963): A reevaluation of the early history of the frogs. Part II. - Systematic Zoology, 12: 20-35. http://dx.doi.org/10.2307/2411892

Hecht, M. K. (1970): The Morphology of Eodiscoglossus, a Complete Jurassic Frog. - American Museum Novitates, 2424: 1-17.

Jones, M. E. H., Evans, S. E., Sigogneau-Russell, D. (2003): Early Cretaceous frogs from Morocco. - Annals of the Carnegie Museum, 72: 65-97.

Leonardi, P. (1957): La evolución biológica. - Fax, Madrid. $405 \mathrm{pp}$.
Lynch, J. D. (1973): The Transition from Archaic to Advanced frogs. - In: Vial, J. L. (ed.), Evolutionary Biology of the Anurans. Contemporary Research on Major Problems, University of Missouri Press, Columbia, pp. $133-182$.

Marjanović, D., Laurin, M. (2014): An updated paleontological timetree of lissamphibians, with comments on the anatomy of Jurassic crown-group salamanders (Urodela). - Historical Biology, 26: 535-550. http://dx.doi.org/10.1080/08912963.2013.797972

Martin, C., Alonso-Zarazaga, M. A., Sanchiz, B. (2012): Nomenclatural notes on living and fossil amphibians. Graellsia, 68: 159-180. http://dx.doi.org/10.3989/graellsia.2012.v68.056

Martínez-Closas, C., López Morón, N. (1995): The Charophyte flora. - In: Martínez Delclos, X. (ed.), Montsec \& Montral-Alcover. Two Konservat-Lagerstatten, Catalonia, Spain, Institut d'Estudis Ilerdencs, Lleida, pp. 29-31.

Noble, G. K. (1931): The Biology of the Amphibia. McGraw-Hill, New York, 577 pp. http://dx.doi.org/10.5962/bhl.title.82448

Oken, L. (1816): Lehrbuch der Naturgeschichte. Vol. 3. Zoologie. Abtheilung 2. Atlas. - C. H. Reclam, Leipzig, $1270 \mathrm{pp}$.

Otth, A. (1831): Beschreibung einer neuen europäischen Froschgattung, Discoglossus. - Neue Denkschriften der Allgemeinen Schweizerischen Gesellschaft für die Gesammten Naturwissenschaften, 1: 1-8.

Piveteau, J. (1955): Anoura. - In: Piveteau, J. (ed.), Traité de Paléontologie, Tome V: Amphibiens, Reptiles, Oiseaux, Éd. Masson, Paris, pp. 250-274.

Pyron, R. A., Wiens, J. J. (2011): A large-scale phylogeny of Amphibia including over 2,800 species, and a revised classification of extant frogs, salamanders, and caecilians. - Molecular Phylogenetics and Evolution, 61: 543-583. http://dx.doi.org/10.1016/j.ympev.2011.06.012

Roček, Z. (1994): Taxonomy and distribution of Tertiary discoglossids (Anura) of the genus Latonia v. Meyer, 1843. - Geobios, 27: 717-751. http://dx.doi.org/10.1016/S0016-6995(94)80058-8

Roček, Z. (2000): Mesozoic anurans. - In: Heatwole, H., Carroll, R. L. (eds), Amphibian Biology 4, Surrey Beatty and Sons, Chipping Norton, pp. 1295-1351.

Roelants, K., Bossuyt, F. (2005): Archaeobatrachian paraphyly and Pangaean diversification of crown-group frogs. - Systematic Biology, 54: 111-126. http://dx.doi.org/10.1080/10635150590905894

Ruane, S., Pyron, R. A., Burbrink, F. T. (2011): Phylogenetic of the Cretaceous frog Beelzebufo from Madagascar and the placement of fossil constraints based on temporal and phylogenetic evidence. - Journal of Evolutionary Biology, 24: 274-285. http://dx.doi.org/10.1111/j.1420-9101.2010.02164.x

Ruiz-Omeñaca, J. I., Canudo, J. I., Aurell, M., Bádenas, B., Barco, J. L., Cuenca-Bescós, G., Ipas, J. (2004): Estado de las investigaciones sobre los vertebrados del Jurásico Superior y Cretácico Inferior de Galve (Teruel) [State of the investigations on the vertebrates from the Upper Jurassic and Lower Cretaceous of Galve (Teruel)]. Estudios Geológicos, 60: 179-202. (in Spanish) 
Sanchiz, B. (1998): Salientia (Encyclopedia of Paleoherpetology, Part 4). - Verlag Dr. Friedrich Pfeil, München, $275 \mathrm{pp}$.

San Mauro, D. (2010): A multilocus timescale for the origin of extant amphibians. - Molecular Phylogenetics and Evolution, 56: 554-561. http://dx.doi.org/10.1016/j.ympev.2010.04.019

San Mauro, D., Vences, M., Alcobendas, M., Zardoya, R., Meyer, A. (2005): Initial Diversification of Living Amphibians Predated the Breakup of Pangea. - The American Naturalist, 165: 590-599. http://dx.doi.org/10.1086/429523

Stejneger, L. (1899): Description of a new genus and species of discoglossid toad from North America. - Proceedings of the United States National Museum, 21: 899-901. http://dx.doi.org/10.5479/si.00963801.21-1178.899

Taylor, E. H., Noble, G. K. (1924): A new genus of discoglossid frogs from the Philippine Islands. American Museum Novitates, 121: 1-4.

Vergnaud-Grazzini, C., Wenz, S. (1975): Les discoglossidés du Jurassique supérieur du Montsech (Province de Lérida, Espagne). - Annales de Paleontologie (Vertebres), 61: 19-36.
Villalta, J. F. de (1954): Novedades paleomastológicas desde el último cursillo (1952) [Palaeomastozoological news since the latest short course (1952)]. - II Cursillo Internacional Paleontología, Museo de Sabadell, Sabadell, 9 pp. (in Spanish)

Wagler, J. G. (1830): Natürliches System der Amphibien, mit vorangehender Classification der Säugthiere und Vogel. Ein Beitrag zur vergleichenden Zoologie. - J. G. Cotta, München, Stutgart and Tübingen, 354 pp.

Wang, Y. (as W. Yuan), Gao, K. (as Keqin, G.), Xu, X. (as Xing, X) (2000): Early evolution of discoglossid frogs: new evidence from the Mesozoic of China. - Naturwissenschaften, 87: 417-420. http://dx.doi.org/10.1007/s001140050753

Warren, D. E., Jackson, D. C. (2005): The role of mineralized tissue in the buffering of lactic acid during anoxia and exercise in the leopard frog Rana pipiens. - Journal of Experimental Biology, 208: 111-1124. http://dx.doi.org/10.1242/jeb.01490

Wiens, J. J. (2007): Global patterns of diversification and species richness in amphibians. - The American Naturalist, 170 (supplement): S86-S104. http://dx.doi.org/10.1086/519396 